Vol. 3, No. 1, 2020

\author{
N. Ya. Monka, H. M. Khomitska, S.V. Vasyliuk, L. V. Fizer, L. D. Bolibrukh, V. I. Lubenets \\ Lviv Polytechnic National University, \\ Department of Technology of Biologically Active Compounds, Pharmacy and Biotechnology \\ mnatalija1985@gmail.com
}

\title{
SYNTHESIS AND PROPERTIES OF 4,6-DIMETHYLPYRIMIDINE-2-YL ESTERS OF AROMATIC THIOSULFOACIDS
}

https://doi.org/

Methods for the synthesis of thiosulfoesters with a pyrimidine moiety were investigated by the interaction of sulfinic acids with 4,6-dimethylpyrimidine-2-yl sulfenamide. The interaction of 4,6-dimethylpyrimidin-2-yl esters of aromatic thiosulfoacids with amines (benzylamine, morpholine, ammonia) was investigated. It is established that the interaction of synthesized 4,6dimethylpyrimidin-2-yl thiosulfoacid esters with different amines is interesting not only in terms of studying the properties of thiosulfoesters, but also as an interaction with significant practical value, since it can be proposed for use as a new method of synthesis pyrimidine sulfenamides. The structure and individuality of the synthesized compounds were confirmed by IR, ${ }^{1} \mathrm{H}$ NMR spectroscopy, elemental analysis and TLC method.

Keywords: aromatic thiosulphoacid salts, thiosulphonates, alkylation, thiosulphoesters with pyrimidine moiety.

\section{Introduction}

Increased attention of researchers working in the field of medical chemistry attracts pyrimidine derivatives. However, despite the rich history of searching for potential biologically active agents among the substances containing the heterocyclic moiety, their potential is still not exhausted. It was confirmed by the large number of pyrimidine-containing medicines with diversified activity, in particular, antiviral (idoxuridine, tenofovir, peciclovir), antimetabolite (ralitrexel), diuretic (triamterene), etc. [1]. Among pyrimidine derivatives it was found vasodilators, antidiabetic, antibacterial, antimalarial substances [2]. Also,barbituric acid derivatives are widely used as hypnotics and anticonvulsants [3]. Substances containing the pyrimidine cycle are widespread in nature, since they are involved in plenty important biological processes, in particular, are includedin nucleotides. In addition, pyrimidine cycle is a fragment of some $\mathrm{B}$ vitamins, namely $\mathrm{B}_{1 \text {, }}$ coenzymes and antibiotics. The study of the properties of new derivatives of condensed nitrogencontaining compounds with a pyrimidine moiety is important in order to create effective antimicrobial agents for prevention and treatment of infectious complications $[4,5]$.

Pyrimidine derivatives have been introduced into medical practice for the treatment of cancer, as the active substances of the drugs dopanum, nimustine, fluorouracil, cytarabine, ftorafur [2].

The heterocyclic pyrimidine system is the structural basis of many naturally occurring physiologically active substances that are fundamental for cell life (purine alkaloids, nucleic acids, DNA, RNA, etc.).

Particularly important as biologically active substances are sulfur-containing pyrimidine derivatives (sulfides, sulfoacid salts, sulfonamides, sulfenamides, disulfides). Among them it was found plant growth regulators [6, 7], herbicides, insecticides and acaricides, fungicides and bactericides [8, 9], herbicide antidotes and others. Also, pyrimidine derivatives serve as intermediates for the synthesis of a number of active organophosphorus insecticides and derivatives of carbamic acid and urea derivatives. Pyrimidine derivatives have been used as hardness stabilizers of vulcanized rubber compositions [10], as building blocks in polymer 
chemistry for the introduction of functional end groups into polymers [11], in color photography as a new type of against foggy compounds [12], and also as nitrogen-containing chemical reagents.

Sulfur-containing compounds - thiosulfonates, are important as effective sulfenilation and sulfonilation chemical reagents that can react with a nucleophile, electrophile and radicals $[11,13,14]$, as well as practically valuable compounds, that exhibit a wide range of biologicaleffects $[15,16,17,18,19]$. Nevertheless in literature, there is limited data on the synthesis of pyrimidine sulfur-containing derivatives, particular thiosulfoacid esters with pyrimidine moiety.

Therefore, the aim of this work is the development of method for synthesis and research of chemical properties of pyrimidine esters of thiosulfoacids.

\section{Materials and methods of study}

IR spectra were taken on a spectrophotometer SPECORD M 80 (KBr pellets); ${ }^{1} \mathrm{H}$ NMR spectra were recorded on a spectrometerVarian VXR-300, $\left({ }^{1} \mathrm{H}\right.$ chemical shifts are expressed in $\delta$ - a scale relative to tetramethylsilane, solvent - DMSO-D 6 , and the integral intensities correspond to the attributions that were made); purityof the synthesized compounds were monitored by TLC and elemental analysis performed on standard microanalysis equipment.

Methodology 1. S-(4,6-dimethylpyrimidin-2yl)thiohydroxylamine 2

At a temperature of $-3 \div-4{ }^{\circ} \mathrm{C}$ to $240 \mathrm{ml}$ of cooled $5 \%$ ammonia solution in small quantities with constant stirring was added $80 \mathrm{ml}$ sodium hypochlorite solution. The resulting solution of chloramine was quickly poured into a solution of 8.4 g (0.06 mol) chlorohydrate of 4,6-dimethyl-2mercaptopyrimidine in $60 \mathrm{ml}$ of $2 \mathrm{~N}$ potassium hydroxide solution. After an hour at room temperature, the precipitate was filtered off and washed with ice water on the filter and was dried.

The yield of S-(4,6-dimethylpyrimidin-2yl)thiohydroxylamine with $\mathrm{T}_{\mathrm{mp}}=100{ }^{\circ} \mathrm{C}$ was $6.2 \mathrm{~g}$ (84\%).
Methodology 2. S-(4,6-dimethylpyrimidin-2yl)benzenesulfonothioate $4 a$

To a solution of $23.8 \mathrm{~g}(0.16 \mathrm{~mol})$ of benzenesulfinic acid 3a in $51 \mathrm{ml}$ of ethanol and $19.5 \mathrm{ml}$ of water was added a solution of $12.9 \mathrm{~g}$ (0.08 mol)of S-(4,6-dimethylpyrimidin-2-yl)thio-

hydroxylamine in $140 \mathrm{ml}$ of ethanol and $86 \mathrm{ml}$ of water. After one hour at $20{ }^{\circ} \mathrm{C}$, the precipitate was filtered off, washed several times with water and 30 $\%$ ethanol, recrystallized from ethanol. The yield of thiosulfoester $4 \mathbf{a}$ with $\mathrm{T}_{\mathrm{mp}}=114-115{ }^{\circ} \mathrm{C}$ was $17.8 \mathrm{~g}$ $(76,39 \%)$.

Methodology 3. S-(4,6-dimethylpyrimidin-2yl)4-((methoxycarbonyl)amino)benzenesulfonothioate $4 b$.

To a solution of $17.5 \mathrm{~g}(0.08 \mathrm{~mol})$ of $4-$ [(methoxycarbonyl)amino]benzenesulfoacid $\mathbf{3 b}$ in $110 \mathrm{ml}$ of ethanol and $67 \mathrm{ml}$ of water was added a solution of $6.2 \mathrm{~g}$ (0.04 mol) of S-(4,6-dimethylpyrimidine-2-yl)thiohydroxylamine 2 in $55 \mathrm{ml}$ of ethanol and $16 \mathrm{ml}$ of water.

After one hour at $20{ }^{\circ} \mathrm{C}$, the precipitate was filtered off, washed several times with water, recrystallized from ethanol. The yield of thiosulphoester $\mathbf{4 b}$ with $\mathrm{T}_{\mathrm{mp}}=182^{\circ} \mathrm{C}$ was $5.8 \mathrm{~g}(41.08 \%)$.

Methodology 4. S-(4,6-dimethylpyrimidin-2$y$ l)ethanesulfonothioate $4 c$.

Solution of $4.6 \mathrm{~g}(0.048 \mathrm{~mol})$ of the sodium ethanesulfinate in mixture of $20 \mathrm{ml}$ of ethanol and 10 $\mathrm{ml}$ of water was acidified with concentrated hydrochloric acid to $\mathrm{pH}=2$. To the resulting solution was added a solution of $3.08 \mathrm{~g}(0,022 \mathrm{~mol})$ 4,6-dimethylpirymidyn-2-yl sulfenamide of 3c. After hour at $20{ }^{\circ} \mathrm{C}$, the solution was cooled, by water ester $\mathbf{4 c}$ was sedimented,then filtered. The purification was carried out by recrystallization from aqueous ethanol (1:1). The yield of product $4 \mathbf{c} \mathrm{T}_{\mathrm{mp}}=$ 63-65 ${ }^{\circ} \mathrm{C}$ was $1 \mathrm{~g}(21.5 \%)$.

Methodology 5 . S-(4,6-dimethylpyrimidin-2yl)benzenesulfonothioate 4 a with benzylamine.

To a suspension of $5 \mathrm{~g}(0.018 \mathrm{~mol})$ of pyrimidine ester $4 \boldsymbol{a}$ in $70 \mathrm{ml}$ of absolute ether, $4.18 \mathrm{~g}$ (0.039 mol) of benzylamine was added. After 7-hour exposure at $20{ }^{\circ} \mathrm{C}$ the precipitate of benzylamino salt of benzenesulfinic acid $\mathbf{6 a}$ was filtered. From the 
filtrate, ether was removed by a stream of dry air, and N-benzyl-1-(4,6-dimethylpyrimidin-2-yl)4sulfanimine 5a was purified by recrystallization from ethanol. The yield of sulfenamide $\mathbf{5 a}$ with $\mathrm{T}_{\mathrm{mp}}=51-52$ ${ }^{\circ} \mathrm{C}$ was $1.9 \mathrm{~g}(42.60 \%)$.

Purification of salt 6a was performed by recrystallization from ethanol. The yield of salt 6a with $\mathrm{T}_{\mathrm{mp}}=160-162{ }^{\circ} \mathrm{C}$ was $1.8 \mathrm{~g}(41,14 \%)$.

Methodology 6. S-(4,6-dimethylpyrimidin-2yl)benzenesulfonothioate 4 a with morpholine.

$2.5 \mathrm{~g}(0.028 \mathrm{~mol})$ of freshly distilled morpholine was added to a solution of $3.9 \mathrm{~g}$ $(0.014 \mathrm{~mol})$ of pyrimidine ester $4 \boldsymbol{a}$ in $30 \mathrm{ml}$ of unhydrous chloroform. After 48 hours exposure of reaction mass, chloroform was distilled off in vacuo. The insoluble morpholinamide of 4,6dimethylpyrimidin-2-ylsulfenic acid $\mathbf{5 b}$ was filtered off, purified by recrystallization from ethanol. The yield of sulfenamide $\mathbf{5 b}$ with $\mathrm{T}_{\mathrm{mp}}=96-97{ }^{\circ} \mathrm{C}$ was 0.9 $\mathrm{g}(28.2 \%)$.

In vacuum from the aqueous solution water was evacuated. The yield of the benzenesulfinic salt of morpholine6b was $1,04 \mathrm{~g}(68.4 \%)$. The obtained salt of morpholine $\mathbf{6 b}$ was a viscous syrupy liquid that does not crystallize at $-5{ }^{\circ} \mathrm{C}$. Purification was carried out by re-precipitation from the alcohol-ether mixture.

Methodology 7. S-(4,6-dimethylpyrimidin-2yl)4-((methoxycarbonyl)amino)benzenesulfonothioate $4 b$ with gaseous ammonia.

Through a suspension of $4 \mathrm{~g}(0.012 \mathrm{~mol})$ of ester $\mathbf{4 b}$ in $80 \mathrm{ml}$ of anhydrous chloroform at a temperature of $0 \div 4{ }^{\circ} \mathrm{C}$ was passed gaseous ammonia for 1 hour. The completion of the reaction was determined by the complete solubility in water of the sediment sample from the reaction mass. After 1 hour exposure, the ammonium salt of 4 [(methoxy-carbonyl)amino]

benzenesulfinicacid $\mathbf{3 c}$ was filtered off, washed with chloroform, recrystallized from ethanol.

The yield of thiosulfoester 6 is $1.7 \mathrm{~g}(64.4 \%)$, $\mathrm{T}_{\mathrm{mp}}=150{ }^{\circ} \mathrm{C}$.

The chloroform filtrate was distilled off in vacuo, the residue was washed with water and cold ethanol. The yield of 4,6-dimethyl-2-sulfenamide of pyrimidine $21.7 \mathrm{~g}(96.52 \%), \mathrm{T}_{\mathrm{mp}}=99-100{ }^{\circ} \mathrm{C}$. A sample of mixing the obtained sulfenamide with the product obtained by counter-synthesis by a known method, the depression of the melting point was not given.

Methodology 8. S-(4,6-dimethylpyrimidin-2yl)benzenesulfonothioate $4 a$ with $\mathrm{KOH}$ solution in ethyl alcohol

To a suspension of $5 \mathrm{~g}(0.018 \mathrm{~mol})$ of ester $\mathbf{4 a}$ solution of potassium hydroxide $(1 \mathrm{~g} \mathrm{KOH}$ in $20 \mathrm{ml}$ of ethanol) was added in $100 \mathrm{ml}$ of ethanol. After exposure for 20 hours at $20{ }^{\circ} \mathrm{C}$, from the reaction mass the solvent was removed in vacuo, the residue was treated with water, the insoluble precipitate was recrystallized twice from ethanol.

Yield of disulfide 7 was1.3 $\mathrm{g}(26.2 \%), \mathrm{T}_{\mathrm{mp}}=$ $157-160{ }^{\circ} \mathrm{C}$.

The aqueous solution was evaporated to dryness to obtain potassium benzene-sulfinate 8a after purification by recrystallization from ethanol in $1 \mathrm{~g}(33.3 \%)$. Potassium benzenesulfinate 8a was identified by conversion to benzenesulfinic acid, the temperature of melting point of which corresponds to the literature $\left(\mathrm{T}_{\mathrm{mp}}=84-85^{\circ} \mathrm{C}\right)$.

Methodology 9. S-(4,6-dimethylpyrimidin-2yl)4-((methoxycarbonyl)amino)benzenesulfonothioate $4 b$ withKOH solution in ethyl alcohol

To a suspension of $5 \mathrm{~g}(0.015 \mathrm{~mol})$ of S- ester $4 \boldsymbol{b}$ in $90 \mathrm{ml}$ of ethanol, solution of potassium hydroxide $(0.83 \mathrm{~g}$ of $\mathrm{KOH}$ in $20 \mathrm{ml}$ of the same alcohol) was added. After exposure for $20 \mathrm{~h}$ at $20^{\circ} \mathrm{C}$ from the reaction mass, the solvent was removed in vacuo, and the residue was treated twice with a small amount of water, the insoluble precipitate was recrystallized from ethanol.

Yield of disulfide 7 was $2.9 \mathrm{~g}(73.6 \%), \mathrm{T}_{\mathrm{mp}}=$ $160{ }^{\circ} \mathrm{C}$. lit. $\mathrm{T}_{\mathrm{mp}}=155^{\circ} \mathrm{C}$ sample mixing with known disulfide $\mathrm{T}_{\mathrm{mp}}=157-160^{\circ} \mathrm{C}$.

The aqueous solution was evaporated to dryness to obtain the potassium salt of 4-methoxycarbonylaminobenzenesulfinic acid $\mathbf{8 b}$ to yield $0.9 \mathrm{~g}$ $(25.14 \%)$. Salt was identified by its conversion to $4-$ [(methoxycarbonyl)amino]benzenesulfinic acid, which was isolated by treatment with hydrochloric acid. $\mathrm{T}_{\mathrm{mp}}=150-155^{\circ} \mathrm{C}$.lit. $\mathrm{T}_{\mathrm{mp}}=145-150^{\circ} \mathrm{C}$. Sample mixing of the obtained 4-[(methoxycarbonyl)amino]benzenesulfinic acid with product 
that was obtained by known methods, the depression of the melting point did not give.

\section{Results of the studies and discussion}

In continuation of our research on the synthesis of thiosulfoesters with the pyrimidine moiety from thiol sulfur side [20] it was carried out the reactionof sulfinic acids with 4,6-dimethylpirymidyn-2-yl sulphenamide.

With this aim, two ways to obtain 4,6dimethylpyrimidin-2-yl sulphenamide were investigated, directly from free base of 4,6-dimethylpyrimidine-2-thiol and from its chlorohydrate.

While obtaining of 4,6-dimethylpyrimidin-2yl sulphenamide directly from the free base of 4,6dimethyl-2-mercaptopyrimidine, the chlorohydrate of the latter was pre-treated with a dilute $(13 \%)$ solution of ammonia. The desired sulfanilamide 2 was obtained with the yield of $46.1 \%$, based on the starting chlorohydrate of 4,6-dimethyl-2mercaptopyrimidine. The low yield of 4,6dimethylpyrimidin-2-yl sulphenamide can obviously be explained by the significant losses in the free base step of 4,6-dimethyl-2-mercaptopyrimidine, since the latter is partially soluble in water.

In view of this, sulfanilamide $\mathbf{2}$ is more appropriate to be obtained directly from mercaptopyrimidine chlorohydrate 1 by the action of chloramine in an aqueous alkaline medium.<smiles>Cc1cc(Cl)c(N)nc1N(Cl)Cl</smiles>

Using such method of synthesis, the yield of the target product 3 is higher $(84.93 \%)$ and the process time is significantly reduced.

Sulfinic acids $\mathbf{3}$ a-cwere pre-synthesized by reduction of the corresponding sulfochlorides with sodium sulfite in an alkaline medium or by zinc in an alcoholic medium, depending on the structure of the sulfinic acid.

The interaction of 4,6-dimethylpyrimidin-2-yl sulfenamide 2 with aromatic and aliphatic sulfinic acids 3 a-chas been investigated in different solvents under different temperature conditions.

It was found that it is reasonably to carry out the reaction in an alcohol-aqueous medium at room temperature. The target 4,6-dimethylpyrimidin-2- yl S-esters of the corresponding thiosulfonic acids $\mathbf{4}$ a-c wereobtained in yields of $22-76 \%$.

Scheme 2

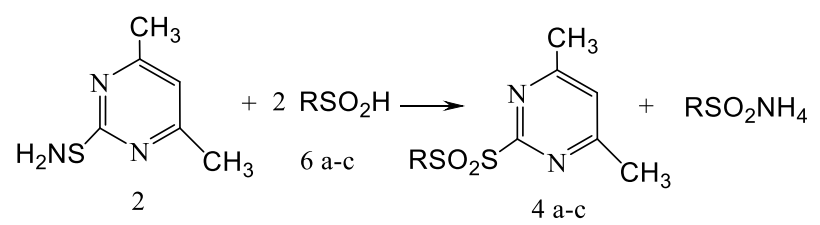<smiles>[R]C1=CCC(C2CCCC(NC(=O)OCCCCCO)C2)CC1</smiles>

The physicochemical characteristics of compounds 7 a-c are shown in Table 1.

Table 1

\section{Characteristics of the synthesized compounds 4a-c}

\begin{tabular}{|c|c|c|c|c|c|c|}
\hline \multirow[t]{2}{*}{ № } & \multirow{2}{*}{$\begin{array}{c}\text { Yield, } \\
\%\end{array}$} & \multirow[t]{2}{*}{$\begin{array}{l}\mathrm{T}_{\mathrm{mp}} \\
{ }^{0} \mathrm{C}\end{array}$} & \multicolumn{4}{|c|}{$\begin{array}{c}\text { Found, } \% \\
\text { Calculated, } \%\end{array}$} \\
\hline & & & $\mathrm{C}$ & $\mathrm{H}$ & $\mathrm{N}$ & $S$ \\
\hline \multirow{2}{*}{$4 a$} & \multirow{2}{*}{76} & 114- & 51,03 & 4,25 & 9,88 & 22,69 \\
\hline & & 115 & 51,43 & 4,29 & 10,00 & 22,86 \\
\hline \multirow{2}{*}{$4 b$} & \multirow{2}{*}{41} & $182-$ & 47,13 & 4,21 & 11,78 & 18.01 \\
\hline & & 183 & 47,59 & 4,25 & 11,90 & 18,13 \\
\hline \multirow{2}{*}{$4 c$} & \multirow{2}{*}{21} & \multirow{2}{*}{$3-$} & $\underline{41,02}$ & $\underline{5,12}$ & 12,48 & 27,42 \\
\hline & & & 41,38 & 5,17 & 12,07 & 27,59 \\
\hline
\end{tabular}

The structure and individuality of the first synthesized thiosulphoesters $\mathbf{4}$ a-cwere confirmed by IR data, ${ }^{1} \mathrm{H}$ NMR spectroscopy (Table 2), elemental analysis (Table 1) and TLC method.

In the IR spectrum of 4,6-dimethylpyrimidin2-S-ester of ethanethiosulfoacid $\mathbf{4} \mathbf{c}$ it is observed intense absorption band at $1145_{\gamma_{\mathrm{s}}}$ and $1312_{\gamma \text { as }}$ $\mathrm{cm}^{-1}$ characteristic of symmetric and asymmetric stretching vibration of $\mathrm{SO}_{2}$ group. In addition, the IR spectra exhibit less intense absorption bands at 1452, 1518, 1512, and 1582, $1590 \mathrm{~cm}^{-1}$, which are characteristic of the valence vibrations of the pyrimidine cycle [11]. 
Table 2

\section{IR data and ${ }^{1} \mathrm{H}$ NMR spectroscopy of compounds 4 a-c}

\begin{tabular}{|c|c|c|}
\hline $\begin{array}{l}\text { № } \\
\text { сп }\end{array}$ & $\begin{array}{c}\text { IR spectrum, } \\
\text { absorption frequency } \\
v, \mathrm{~cm}^{-1}\end{array}$ & $\begin{array}{l}{ }^{1} \mathrm{H} \text { NMR spectrum, } \\
\text { chemical shift } \delta, \mathrm{ppm}\end{array}$ \\
\hline $4 a$ & $\begin{array}{c}1588,1522-1482 \\
1460,(\text { pyrimidine } \\
\text { cycle); } 1580(\mathrm{Ar}) ; \\
1320_{\gamma \mathrm{as},} 1135_{\gamma \mathrm{s}}, \\
\left(\mathrm{SO}_{2}\right) ;\end{array}$ & $\begin{array}{l}2.54\left(6 \mathrm{H}, \mathrm{s}, \mathrm{CH}_{3}\right), 7.13(1 \\
\mathrm{H}, \mathrm{s}, \mathrm{CH}-\mathrm{Het}) 7.70- \\
7.84(3 \mathrm{H}, \mathrm{m}, \mathrm{CH}-\mathrm{Ar}) \\
8.04(2 \mathrm{H}, \mathrm{d}, J=6.60 \mathrm{~Hz}, \\
\mathrm{CH}-\mathrm{Ar})\end{array}$ \\
\hline $4 b$ & $\begin{array}{c}3338(\mathrm{NH}) ; 1670, \\
1626,(\mathrm{C}=\mathrm{O}) ; 1588 \\
(\mathrm{Ar}) ; 1586,1544, \\
1458,(\text { pyrimidine } \\
\text { cycle }) ; 1315_{\gamma \mathrm{as}, 1132_{\gamma \mathrm{s}}} \\
\left(\mathrm{SO}_{2}\right) ;\end{array}$ & $\begin{array}{l}2.52\left(6 \mathrm{H}, \mathrm{s}, \mathrm{CH}_{3}\right), 3.28 \\
\left(3 \mathrm{H}, \mathrm{s}, \mathrm{CH}_{3}\right), 7.08(1 \mathrm{H}, \\
\mathrm{s}, \mathrm{CH}-\mathrm{Het}) 7.36(2 \mathrm{H}, \mathrm{d}, \\
J=9.60 \mathrm{~Hz}, \mathrm{CH}-\mathrm{Ar}) \\
8.19(2 \mathrm{H}, \mathrm{d}, J=9.60 \mathrm{~Hz}, \\
\mathrm{CH}-\mathrm{Ar}), 9.98 \quad(1 \mathrm{H}, \mathrm{c}, \\
\mathrm{NH})\end{array}$ \\
\hline $4 c$ & 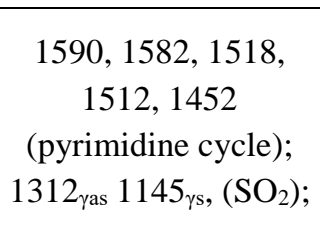 & $\begin{array}{l}1.34(3 \mathrm{H}, \mathrm{t}, J=7.53 \mathrm{~Hz}, \\
\left.\mathrm{CH}_{3}\right) 2.36\left(6 \mathrm{H}, \mathrm{s}, \mathrm{CH}_{3}\right), \\
3.86(2 \mathrm{H}, \mathrm{q}, J=7.70 \\
\left.\mathrm{Hz}, \mathrm{CH}_{2}\right), 7.17(1 \mathrm{H}, \mathrm{s}, \\
\mathrm{CH}-\mathrm{Het})\end{array}$ \\
\hline
\end{tabular}

In the IR spectra of such pyrimidine esters benzene-and carbmethoxyaminobenzenethiosulfoacid $4 \mathbf{a}, \mathbf{b}$ arepresent absorption bands due to stretching vibrations of pyrimidine core at 1460 , $1482-1522,1588 \mathrm{~cm}^{-1}$ for compound $\mathbf{4} \mathbf{a}$ and according to compound $\mathbf{4} \mathbf{b}$ strip - 1458, 1544, $1586 \mathrm{~cm}^{-}$ 1. Absorption of the $\mathrm{SO}_{2}$ group in these compounds is shown by sufficiently intense bands of symmetric valence vibrations of $1135 \mathrm{~cm}^{-1}$ for $\mathbf{4 a}$ and $1132 \mathrm{~cm}^{-1}$ for $\mathbf{4 b}$, asymmetric valence oscillations are expressed less clearly at $1320 \mathrm{~cm}^{-1}$ in the benzentiosulfonic acid ester and $1315 \mathrm{~cm}^{-1}$ 4-carbmethoxyaminobenzene-thiosulphoacid. In addition, in compounds $\mathbf{4} \mathbf{a}, \mathbf{b}$ there are bands, respectively, at 1580 and $1588 \mathrm{~cm}^{-1}$ characteristic of aromatics. In the IR spectrum of thethioester 4b there are absorption bands $1670 \mathrm{~cm}^{-1}$ characteristic of $\mathrm{C}=\mathrm{O}$ and $1626,3338 \mathrm{~cm}^{-1}$ characteristic of the $\mathrm{NH}$ group.

Taking into account the considerable chemical potential esters of thiosulphoacid, it was investigated some chemical properties of thiosulphoesters with a pyrimidine moiety. Particularly important among the reactions characteristic of the above-mentioned compounds are nucleophilic substitution reactions. Esters of thiosulfoacids easily interact with nucleophilic agents like thiols, organometallic compounds, amines, alkalis. This ability of thiosulfoacid esters is due to the presence of a partial positive charge on the divalent sulfur atom.

The interaction of 4,6-dimethylpyrimidine-2yl esters of aromatic thiosulfoacids with amines (benzylamine, morpholine, ammonia) was investigated in anhydrous solvents (diethyl ether, chloroform) at room temperature and at a molar ratio of reagents 1:2.

Under these conditions, the 4,6-dimethylpyrimidin-2-yl ester of benzenethiosulfo acid $\mathbf{4}$ a with benzylamine and morpholine formed respectivelybenzylamine $\mathbf{6}$ a andmorpholine 6 bsaltsofb enzenesulfinic acid and benzylamide $\mathbf{5}$ aand morpholinamide 5 b 4,6-dimethylpyridine-2ylsulfenic acid.

Scheme 3

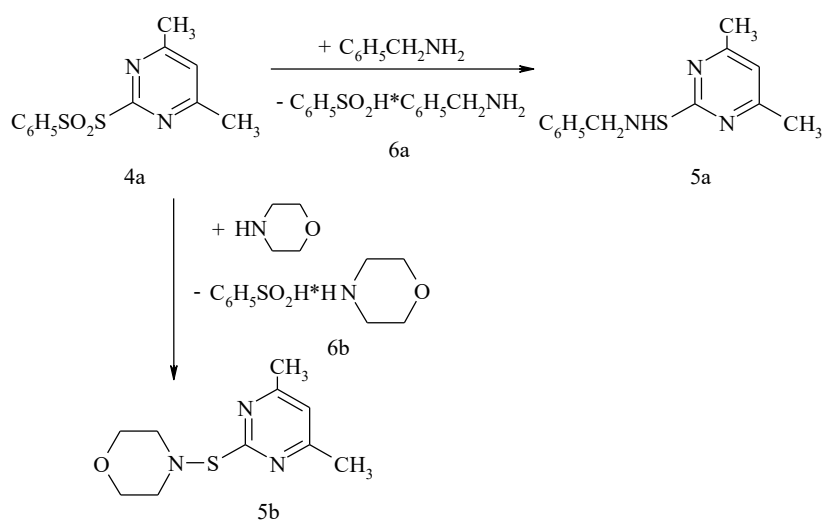

In the study of the interaction of S-(4,6dimethylpyrimidin-2-yl) ester of 4-carbmethoxyaminobenzenethiosulfoacid $\mathbf{4} \mathbf{b}$ with benzylamine it was found that under similar conditions and also while heating, the specified thiosulfoester does not react with benzylamine.

By action of gaseous ammonia on suspension of S-(4,6-dimethylpyrimidin-2-yl) ester of 4carbmethoxyaminobenzenethiosulfoacid $\mathbf{4} \mathbf{b}$ in chloroform at $0-4{ }^{\circ} \mathrm{C}$ was obtained ammonium salt of 4-carbmethoxyaminobenzenesulfinic acid $\mathbf{6} \mathbf{c}$ and 4,6-methylpyrimidin-2-ilsulfenamide 2. 
Scheme 4<smiles>CC(=O)Nc1ccc(S(=O)(=O)c2nc(C)cc(C)n2)cc1</smiles><smiles></smiles>

The ammonium salt $\mathbf{6}$ cwas identified by converting it into 4-carbmethoxyaminobenzenesulfinic acid with a melting point of $150-151^{\circ} \mathrm{C}$ (in literature $-145-150{ }^{\circ} \mathrm{C}$ ), and sulfenamide 2 by the melting point and mixing test with known sulfenamide obtained by counter-synthesis (their mixing dispersion of the melting point did not give).

Analyzing the results we can conclude that the interaction of synthesized 4,6-dimethyl-pyrimidin-2yl thiosulfonic acid esters with different amines is interesting not only in terms of studying the properties of thiosulfoesters, but also as an interaction with significant practical value, since it can be used as a practical new method for the synthesis of pyrimidine sulfenamides. The usual route of synthesis of such compounds - the interaction of sulfenyl chlorides with amines - in this case is not suitable because of the instability and inability to obtain the majority of sulfenyl chlorides of pyrimidine.

Scheme 5

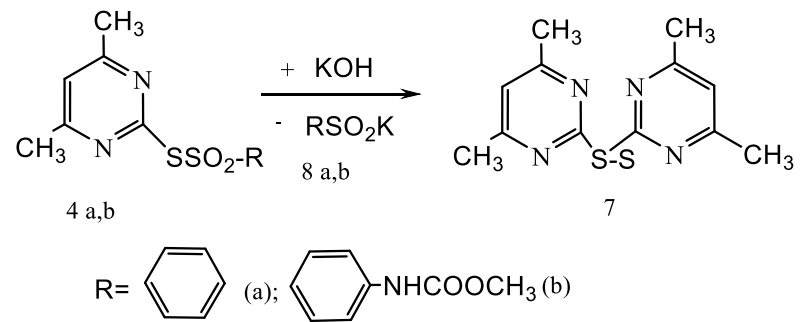

Also there were investigated the interaction of 4,6-dimethylpyrimidin-2-yl thiosulphoesters $\mathbf{4}$ a,b with potassium hydroxide.

While carring out interaction in ethanol at room temperature and $20 \mathrm{~h}$ exposure as reaction products were isolated potassium salts of corresponding sulfinic acids $\mathbf{8} \mathbf{a}, \mathbf{b}$ and pyrimidine disulfide 7.

\section{Conclusions}

A new method for the synthesis of nitrogencontaining heterocyclic thiosulfoesters was proposed.

For the first time, thiosulfoesters with a pyrimidine core from the thiol sulfur moiety were obtained by reacting 4,6-dimethyl-2-sulfenamide pyrimidine with aromatic and aliphatic sulfinic acids in an alcohol-aqueous medium.

The interaction of 4,6-dimethyl-2-pyrimidine esters of thiosulfoacids with nucleophilic reagents (amines, potassium hydroxide) was investigated. It is shown that in an anhydrous solvent medium (diethyl ether, chloroform) at room temperature, thiosulfoesters form sulfinic acid salts and corresponding sulfenic acid derivatives, and in case of instability of the latter, sulfinic acid salts and disulfides were isolated as reaction products. Reactions of pyrimidine thiosulfoesters with amines can be proposed as a new method of synthesis of pyrimidine sulfenamides.

\section{References}

1. Nosulenko I. S. (2018). "Syntez, fizyko-khimichni ta biolohichni vlastyvosti 2-[(3-R-2-okso-2n-[1,2,4]tryazyno[2,3-C]khinazolin-6-il)-tio]otstovykhkyslottayikh pokhidnykh" Dys.kand.farm.nauk.Lviv, 5, 267.

2. Mashkovskyi M. D. (2002) "Lekarstvennye sredstva", 14-e yzd., pererab., yspr. y dop. M.: Novaia volna, $540 \mathrm{~s}$.

3. Chen, Z., Cai, D., Mou, D., Yan, Q., Sun, Y., Pan, W., Wan, Y., Song, H., Yi, W. (2014). Design, synthesis and biological evaluation of hydroxy- or methoxy- 
Synthesis and properties of 4,6-dimethylpyrimidine-2-yl esters of aromatic thiosulfoacids

substituted 5-benzylidene(thio) barbiturates as novel tyrosinase inhibitors. Bioorganic \& Medicinal Chemistry, 22 (13), 3279-3284.

4. Shcherbak, O. M., Andreieva, I. D., Kazmirchuk, V. V., Rusak, P. S., Menkus, O. V. (2012). Perspektyvy zastosuvannia novykh pokhidnykh pirymidynu pry nozokomialnykh infektsiiakh, vyklykanykh hramnehatyvnymy mikroorhanizmamy. Ukrainian journal of surgery. 3(18).

5. Shcherbak, O. M. (2011). Perspektyvy vyvchennia protymikrobnoi dii novykh pokhidnykh 4Npirydo[4',3':5,6]pirano-, [2,3-D]pirymidynu. Aktualni pytannia farmatsevtychnoi $i$ medychnoi nauky ta praktyky, 2(24), 116-118.

6. Melnykov, N. N. (1987) Pestytsydy. Khymyia, tekhnolohyia y prymenenye. Moskva: Khymyia, 712.

7. Kapran, N. A. y dr. (1983). Resp. Mezhved sb. Fyzyolohychesky aktyvnye veshchestva. Naukova dumka, 15, 45-48.

8. Sauers R. F. et al. (1984).Pesticide Synthesis Through Rational Approaches. Washington. 21. 2810.

9. Kreutzberger A. Herbicides. I. et al (1982). 2-(4Nitroanilino)Pyrimidines. Arch. Pharm. 315(1), 2-7.

10. WO 01/70870 A 1. Horng-Jau, L.; RabindraNath, D.; OttoWilliam, M. (2001) Pyrimidin ederivative sashardnessstabilizersforvulcanizablerubbercompositions.

I. App. Numb. PCT/US01/09156; International Filing Date: 21.03 .2001

11. Mampuys P., McElroy C.R., Clark J.H., Orru R.V.A., Maesa B. U. W. (2020). Thiosulfonates as Emerging Reactants: Synthesis and Applications $A d v$. Synth. Catal., 362, 3-64 DOI: 10.1002/adsc.201900864.

12. WO 02/48100 A 1 Shibuya, Isao; Yonemoto, Katsumi; Kaneko, Yutaka; Hirabayashi, Shigeto; Taguchi, Yoichi; Tsuchiya; Yasumoto, Masahiko (2002). Internationales Anmeldedatum: 03.12.2001; Internationales Veröffentlichungsdatum 20.06.2002.

13. Lubenets V. I. (2003). Tiosulfonaty: syntez i vlastyvosti. Ukr. khim.zh., 69 (8), 114-122.

14. Monka N. Ya., Vasyliuk S. V., Nakonechna A. V., Bolibrukh Kh. B., Lubenets V. I. (2018). Estery tiosulfokyslot: oderzhannia, vlastyvosti ta perspektyvy zastosuvannia. Ukr. khim.zh., 84 (9/10), 65-97. Rezhym dostupu: https://ucj.org.ua/index.php/journal/issue/ view/9/10-2018.

15. Vasylyuk S., Komarovska-Porokhnyavets O., Novikov V., Lubenets V. (2018). Modification of alkyl esters of 4-aminobenzenethiosulfonic acid by s-triazine fragment and investigation of their growth-regulative activity Chem. Chem. Technol. 12(1) 24-28.

16. Lubenets V., Stadnytska N., Baranovych D., Vasylyuk S., Karpenko O., Havryliak V. and Novikov V. (2019). Thiosulfonates: The Prospective Substances against Fungal Infections. In: Fungal Infection . Eds. Érico Silva de Loreto and Juliana Simoni Moraes Tondolo, Intech Open, London. DOI: 10.5772/intechopen.84436.

17. Lubenets V., Vasylyuk S., Monka N., Bolibrukh Kh., Komarovska-Porokhnyavets O., Baranovych D., Musyanovych R., Zaczynska E., Czarny A., Nawrot U., Novikov V. (2017). Synthesis and antimicrobial properties of 4-acylaminobenzenethiosulfoacid S-esters.Saudi Pharmaceutical Journal, 25(2), 266-274. http://dx.doi.org/10.1016/j.jsps.2016.06.007

18. Martyrosian I. A., Pakholiuk O. V., Semak B. D., Komarovska-Porokhniavets O.Z., Lubenets V.I., Pambuk S. A. (2019) Novi tekhnolohii efektyvnoho zakhystu tekstyliu vid mikrobiolohichnykh poshkodzhen. Nanosistemi, Nanomateriali, Nanotehnologii, 17(4), 621636.

19. Martirosyan I., Pakholiuk O., Semak B., Lubenets V., Peredriy O. (2020) Investigation of Wear Resistance of Cotton-Polyester Fabric with Antimicrobial Treatment. In: Tonkonogyi V. et al. (eds) Advanced Manufacturing Processes. InterPartner 2019. Lecture Notes in Mechanical Engineering. Springer, First Online 28 March 2020, DOIhttps://doi.org/10.1007/978-3-030-40724-7_44

20. Monka, N. Ia., Baranovych, D. B., Shyian, H. B., Khomitska, H. M., Lubenets, V. I. (2019). Syntez ta vlastyvosti 4-amino-2-metylpirymidyn-5-il-metylovykh esteriv aromatychnykh tiosulfokyslot. Chemistry, Technology and Application of Substances, 2(2), 122-128.

21. Bolshakov, H. F. (1987) YK-spektry y renthenohramy heterotsyklycheskykh soedynenyi. L. "Khymyia". 
N. Ya. Monka, H. M. Khomitska, S. V. Vasyliuk, L. V. Fizer, L. D. Bolibrukh, V.I. Lubenets

Н. Я. Монька, Г. М. Хоміцька, С. В. Василюк, Л. В. Фізер, Л. Д. Болібрух, В. І. Лубенець

Національний університет “Львівська політехніка", кафедра технології біологічно активних сполук, фармації та біотехнології mnatalija1985@gmail.com

\section{СИНТЕЗ ТА ВЛАСТИВОСТІ 4,6-ДИМЕТИЛПІРИМІДИН-2-ІЛОВИХ ЕСТЕРІВ АРОМАТИЧНИХ ТІОСУЛЬФОКИСЛОТ}

Досліджено методи синтезу тіосульфоестерів із піримідиновим фрагментом взаємодісю сульфінових кислот 3 4,6-диметилпіримідин-2-іл сульфенамідом. Досліджено взаємодію 4,6диметилпіримідин-2-ілових естерів ароматичних тіосульфокислот з амінами (бензиламін, морфолін, амоніак). Встановлено, що взаємодія синтезованих 4,6-диметилпіримідин-2-ілових естерів тіосульфокислот із різними амінами є цікавою не лише в плані вивчення властивостей тіосульфоестерів, а також як взаємодія 3 вагомим практичним значенням, оскільки може бути запропонована до використання як новий метод синтезу сульфенамідів піримідину. Будову та індивідуальність синтезованих сполук підтверджено даними ІЧ, ${ }^{1} \mathrm{H}$ ЯМР спектроскопії, елементним аналізом та методом ТШХ.

Ключові слова: солі ароматичних тіосульфокислот, тіосульфонати, алкілування, тіосульфоестери з піримідиновим фрагметом. 